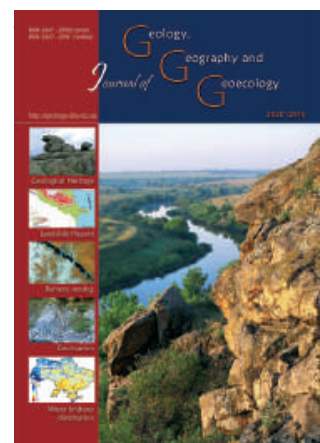

Journal of Geology. Geography and Geoecology

\title{
Tourist potential of Cherkasy region
}

\author{
Viktor V. Hrushka ${ }^{1}$, Natalia A. Horozhankina ${ }^{2}$, Constantin M. Horb ${ }^{2}$ \\ ${ }^{1}$ Oles Honchar Dnipro National University, Dnipro,_Ukraine,Grush_vv@ua.fm \\ ${ }^{2}$ University of Customs and Finance,Dnipro,Ukraine, Nataliagorozhankina@gmail.com, Gorbkm@gmail.com
}

Received: 15.07 .2019

Received in revised form: 15.04 .2020

Accepted: 04.05.2020

Abstract.The resource and recreational potential of Cherkasy region is analyzed. A large number of monuments of archeology, architecture, history, nature, developed centers of traditional crafts and trades, and a fairly dense network of sacred structures stands out among the objects of recreation.Forests and reservoirs play an important role in the recreational area. Conservation areas, which are valuable in recreational terms, occupy $1.2 \%$ of the area of the region. Mineral waters and healing properties of the forest climate are the main manifestations of the recreational properties of space in Cherkasy region. A significant contribution to the resource component of the recreational potential of Cherkasy region was made by a large number of historical and cultural reserves - of which there are 8 in the region, two of which have national status. The sanatorium-resort and preventive-health establishments of the region are considered. It is established that they are represented by sanatoriums (including children's ones), tourist bases and other recreation establishments, whose number is decreasing every year. It is established that according to the capacity index, the largest number of tourists can spend the night at such resorts as «Svitanok» in the village of Svidovok, «Moshnohirya» in the village of Budyshche, «Akvadar» in the town of Mankivka, children's «Ruska Polyana» in the village of Ruska Polyana of Cherkasy district and «Ukraine» and «Sosnoviy bir», which are located in the city of Cherkasy. The most significant recreation facilities are located in the village of Vigraev, Korsun-Shevchenkivskyi district («Ros» VAT «SPK Merydian», «Dubky», «Ros» (Relay and Automation Plant, Kazar-Ros), Prokhorovka village, Kaniv district («Sonyachna», «Komsomolska»), in the village of Chapayevka of the Zolotonisky district («Prydniprovska»).It is established that there is an increase in the number of subjects of tourist activity. More than $80 \%$ of them are travel agencies that are not focused on domestic and inbound tourism. It is found that the transport structure of Cherkasy region is represented by all major passenger types (rail, road, river and air) and its functioning is provided by appropriate infrastructure. The rating of level of development of Cherkasy region on such indicators as hotel infrastructure, restaurant infrastructure, healthimprovement establishments, archeology monuments, architectural monuments and historical monuments was conducted. It is revealed that five districts of the region (Zolotonisky, Kaniv, Uman, Cherkasy, Chyhyryn) have a high level of tourist potential supply, ten districts of the region have a medium level of provision (Horodyshche, Zvenihorod, Kamyansky, Korsun-Shevchenkivsky, Mankiv, Smilyansky, Talne, Khrystyniv, Chornobaiv, Shpolyan), five areas are outsiders with low levels of tourism potential (Drabiv, Zhashkiv, Katerynopil, Lysyansky, Monastyrische).

Keywords: tourism, tourist sites, regional tourist resources, development of regional tourist sites, tourist product

\section{Туристичний потенціал Черкаської області}

\author{
В.В. Грушка ${ }^{1}$, Н.А. Горожанкіна², К.М. Горб²
}

${ }^{1}$ Дніпровський національний університет імені Олеся Гончара, Дніпро, Украӥна, Grush_vv@ua.fm ${ }^{2}$ Університет митної справи та фінансів, Дніпро, Україна, Nataliagorozhankina@gmaìl.com, Gorbkm@gmail.com

Анотація. Проаналізовано ресурсно-рекреаційний потенціал Черкаської області. Серед об'єктів рекреації виділяється велика кількість пам'яток археології, архітектури, історії, природи, розвинуті осередки традиційних ремесел і промислів, досить густа мережа сакральних споруд. У групі рекреаційних угідь важливе місце посідають ліси та водойми. Природоохоронні території, цінні у рекреаційному відношенні, займають $1,2 \%$ площі регіону. Мінеральні води та лікувальні властивості клімату лісових масивів є основними проявами на Черкащині групи рекреаційних властивостей простору. Вагомий внесок у ресурсну складову рекреаційного потенціалу Черкаської області зробила велика кількість історико-культурних заповідників - їх на території регіону 8 , два з яких мають статус національних. Розглянуто санаторно-курортні та профілактично-оздоровчі заклади регіону, встановлено, що вони представлені санаторіями (у тому числі дитячими), базами та іншими закладами відпочинку, кількість яких з кожним роком скорочується. Встановлено, що відбувається збільшення кількості суб'єктів туристичної діяльності, більше ніж 80\% 3 них складають туристичні агентства, які у своїй діяльності не орієнтуються на розвиток внутрішнього та 
в'їзного туризму.3'ясовано, що транспорт Черкаської області представлений всіма основними пасажирськими видами (залізничним, автомобільним, річковим і повітряним) і його функціонування забезпечується відповідною інфраструктурою. Здійснивши бальну оцінку забезпеченості Черкаської області за таким показниками як готельна інфраструктура, ресторанна інфраструктура, лікувально-оздоровчі заклади, пам'ятки археології, пам'ятки архітектури, пам'ятки історії виявлено, що високий рівень забезпеченості туристичним потенціалом мають п’ять районів області (Золотоніський, Канівський, Уманський, Черкаський, Чигиринський), десять районів області мають середній рівень забезпеченості (Городищенський, Звенигородський, Кам'янський, Корсунь-Шевченківський, Маньківський, Смілянський, Тальнівський, Христинівський, Чорнобаївський, Шполянський), п’ять районів-аутсайдерів із низьким рівнем забезпеченості туристичним потенціалом (Драбівський, Жашківський, Катеринопольський, Лисянський, Монастирищенський).

Ключові слова: туризм, туристичні об'єкти, регіональні туристичні ресурси, розвиток регіональних туристичних об'єктів, туристичний продукт

Introduction. Today, the value of tourism in the world is constantly increasing. This is due to the increasing impact of tourism on the economies of many countries in the world. Tourism revenues are seen as an important indicator of its economic importance. Ukraine has considerable natural, historical and economic prerequisites for the development of the tourism industry. However, tourism in our country lacks the proper state support it deserves. As a result, the tourism of Cherkasy region does not find a worthy place in the strategic plans of national and economic development of Ukraine.

An important indicator of the development of tourism in the regions and in the country as a whole is the availability of tourist infrastructure - hotels, sanatoriums, children's health camps, restaurants, cultural establishments and more.

The need to consider the development of tourism potential in Cherkasy region is especially urgent, as this region has powerful tourist and recreational resources. Cherkasy region is a unique region in terms of its historical and cultural significance, geographical location and natural and recreational resources.For the development of the tourism industry in Cherkasy region there are such important prerequisites as an extensive network of transport corridors, proximity to the state capital, mild climate, availability of labour resources (relatively cheap opportunity to use all modes of transport (road, rail, water, air), favourable climate for investors( low internal competitiveness), developed agrarian sector, traditional hospitality of the local population against the background of relatively well preserved ecological status. All these factors create the conditions for the development of ecological tourism and the growth of tourist and recreational complexes.

Research methods. The study applied literary, analytical, comparative, mathematical and statistical methods, method of scientific systematization and point evaluation.

Results and their analysis. Rich historical, cultural, historical-architectural and natural-recreational re- sources are important factors in the development of the tourism industry of Cherkasy region.

There are 4 national and 5 state historical and cultural reserves in Cherkasy region.

In addition, there are 21 state-owned museums, 26 district and city museums, 247 museums and museum rooms created on a public basis, 132 regional and historical monuments and 37 nationally-owned services for tourists and locals. The region also includes the geographical center of Ukraine (Shpolyan district, northern outskirts of Maryanivka village), local tourist sites of national importance, Taras Shevchenko's homeland and site of his burial, the Hetman's capital Chyhyryn, Korsun-Shevchenkivsky.

Within the region there are more than 524 objects of protected areas with a total area of about 63 thousand hectares. They are especially unique landscapes: 21 objects of nature reserve fund of national importance with more developed tourist infrastructure with a total area of about 28 thousand hectares (national parks «Biloozersky» and «Nyzhnosulsky», 4 nature reserves, 6 natural monuments, 6 gardens and monuments, Kaniv Nature Reserve and Cherkasy Zoological Park) (Leonenko, Stetsenko, Vodnyi, 2003, Konovalenko, Karastan, 2006).

Health resorts and preventive-health establishments of Cherkasy region as recreational infrastructural resources attract recreational healthimprovement services. Institutions in the region are represented by sanatoriums (including children's ones), recreational centers and other recreation facilities. It should be noted that during the period 1995-2017 there was a reduction and reorganization of the above mentioned establishments: the number of sanatoriums and boarding houses providing treatment decreased by $22 \%$, tourist bases and other establishments of rest - by $74 \%$. It is particularly discouraging that prophylactic sanatoriums have stopped functioning since 2015 (Holovne, 2019).

Among the region's sanatorium and health resorts (41 units as of 2017), recreation centers (34 units) located by the Kremenchug Reservoir and health resorts 
and boarding houses providing treatment ( 7 units) are prevalent Not all administrative districts of Cherkasy region have similar institutions in their territory: they are located in only 10 districts out of 20 .

An important indicator of accommodation facilities is their capacity. The largest number of tourists can be accommodated for overnight stays at such resorts as «Svitanok» in the village Svydivok (592), «Moshnohirya» in the village Budyshche (500), «Akvadar» in the town of Mankivka (240), children's «Ruska Polyana» in the village Ruska Polyana (205) of Cherkasy region and «Ukraine» (260), «Sosnovyiy bir» (240), which are located in the city of Cherkasy.

Recreation centers of Cherkasy region can accommodate 2,400 guests. The largest recreation centers located in the village of Vigraev, KorsunShevchenkivskyi district («Ros» VAT «SPK Merydian» - 450 places, «Dubky» - 300 places, «Ros» (Relay and Automation Plant, Kazar-Ros) - 260 places, Prokhorovka village, Kaniv district («Sonyachna» - 267 places, «Komsomolska» - 256 places), in the village of Chapayevka of Zolotonsky district («Prydniprovska»- 250 places) (Derzhavna, 2019).

Countryside children's recreation facilities can be used as specialized accommodation in tourism. There are 16 such establishments in Cherkasy region with 2,763 places. Most of the countryside children's health institutions are located in the Zolotonisky district (4 establishments with a capacity of 1,330 people). Two out of town children's camps are located on the outskirts of Cherkasy with a total capacity of 335 places. Zvenyhorod, Kamyansky, Korsun-Shevchenkivsky, Lysyansky, Smilyansky, Khristyniv, Chyhyryn, Shpolyan districts have one such institution that can accommodate 80 to 300 people (Derzhavna, 2019).

It should be noted that tourist-excursion services in Cherkasy region are represented by both tour operators and travel agents, but they are too unevenly spread in the region. The number of licensees of tourist activity is constantly increasing: in 2010, 56 entities were registered, of which 9 were tour operators and others were travel agents, in 2018, 75 enterprises were licensed to perform tourism activities, 15 of which were tour operators, 60 - travel agents (Cherkaska, 2019).

Despite the positive dynamics of the increase in the number of subjects of tourism, more than $80 \%$ of them are travel agencies that are not focused on the development of domestic and inbound tourism.

The overwhelming majority of tourist enterprises are located in the city of Cherkasy; three companies are registered in the cities of Smila and Uman, one in the cities of Zvenyhorodka, Zolotonosha, Kamy- anka, Kaniv, Korsun-Shevchenkivsky, Drabivtsi village of Zolotonisky district and Geronimivka village of Cherkasy district.36 tourism licensees have one branch, 6 have two branches, and two enterprises have.three and four branches The branches mainly work with the head office in one settlement, but there are 5 tourist enterprises registered in Cherkasy region which also have branches located in other regions of Ukraine: Kyiv city, Pryluky city in Chernihiv region, Kremenchug city in Poltava region.There are many branches of tourist companies operating in Cherkasy region, whose main offices are in other regions of Ukraine, including Gamalia, SAM, the network of travel agencies «Horyashchye putevky» and others.

There is a tendency to decrease in the number of tourists served by the tourist activity of Cherkasy region. This situation is related to both objective (such as the global crisis, changing priorities among tourists, insufficient level of infrastructure, unsatisfactory condition of individual objects in the cities of Kaniv and Chyhyryn), and subjective reasons (lack of clear organization in the industry, the lack of regulation of the subjects of tourism in connection with the processes of reorganization).

It can be noted that the uneven placement of tour operators and travel agents throughout Cherkasy region, their excessive concentration in the regional center does not contribute to a balanced development in the field of recreation (in particular, internal and inbound tourism). Recently, the situation has been getting better, as tourism businesses are created in places with a large concentration of recreational facilities.

When considering the hotel infrastructure of the region, it can be noted that both collective and individual accommodation are used to accommodate tourists. However, tourists prefer the first group, and among the collective accommodation facilities hotels are the most popular.In 2018, there were 54 collective accommodation facilities operating in the region (Derzhavna, 2019). The largest number of hotel enterprises is located in the cities of Cherkasy $(27.8 \%$ of the total) and Uman (8.3\%), which are the centers of industrial enterprises and centers of tourist flows.

In 2018, hotel enterprises of Cherkasy region had 1,092 rooms, and their one-time capacity - 2139 places.Although the construction of hotels is underway, the development of the hotel industry is very low. The provision of hotel places per 1,000 residents in Ukraine is on average 2.38.For comparison, we give examples of the leading countries in terms of tourism: in Spain it amounts to 20 places per 1,000 inhabitants, in the USA - 18. The rate of availability of hotel places 
per 1,000 inhabitants on average across Cherkasy region is 1.59 places (the penultimate place among the regions of Ukraine).

According to the calculated indicator of the number of hotel places per 1,000 inhabitants, it is found that it is the highest in Uman district (3.9) and Cherkasy district (2.36 - close to the average in Ukraine) areas. All other districts are lower than the average in Ukraine, in 7 districts per 1,000 inhabitants there is less than 1 place in hotel enterprises, and 4 districts in general do not have hotel type enterprises.

Health-improvement establishments are represented in Cherkasy region by sanatoriums (including children's ones), sanatoriums-prophylactic hospitals, recreation centers.

Accommodation of tourists can be provided in the large country houses used for rural (green) tourism. Although the capacity of these recreational establishments is not very large and this area is just beginning to develop in the Cherkasy region, the possibilities of this type of tourist accommodation should also be taken into account and this infrastructure resource of the region be more widely involved in the implementation of tourism activities.

Transport in Cherkasy region is represented by all major passenger types (rail, road, river and air) and its functioning is provided by appropriate infrastructure.

Railways connect the area with different regions of Ukraine, as well as with other countries. The total length of railways in Cherkasy region is $649.5 \mathrm{~km}$, of which only $22.3 \%$ are electrified. The density of the railway network is $31.4 \mathrm{~km} /$ thousand $\mathrm{km}^{2}$ of the territory of the region, which is significantly lower than the average Ukrainian figure of 37.6 $\mathrm{km} /$ thousand $\mathrm{km}^{2}$. The busiest route in passenger transportation is the section Myronivka - Tsvitkove - Taras Shevchenko - Znamyanka (Holovne, 2019). The rail network of the region needs improvement of technical equipment and increase of throughput.

The basis of the transport infrastructure of the region is the network of national, regional and local highways. Roads of national importance provide transport links to the most important cities in the region, within Ukraine and with other countries. The length of public roads is $6,072.5 \mathrm{~km}$, including $5,884.7$ $\mathrm{km}(96.9 \%)$ with hard surface. The density of roads is $299 \mathrm{~km}$ and $282.1 \mathrm{~km} /$ thousand $\mathrm{km}^{2}$ of the territory of the region, and roads of national importance 29.4 $\mathrm{km} /$ thousand $\mathrm{km}^{2}$ (average Ukrainian density is $21.6 \mathrm{~km} /$ thousand $\mathrm{km}^{2}$ ). On the balance sheet of Cherkasy region there are more than 205 thousand units of rolling stock of motor transport, $76 \%$ of which are cars, and $2 \%$ buses. The developed road network facilitates the development of long-distance and suburban bus services. There are 43 bus stations in the region. Some bus stations do not correspond by the level of technical equipment to the volume of transportation conducted, so they need reconstruction and new bus stations need to be constructed (Holovne, 2019).

River transport is also actively used in the region. The operational length of the navigable waterways of Cherkasy region for general use of the Kremenchug reservoir is $150.0 \mathrm{~km}$, of which $87.8 \mathrm{~km}$ (or $58.5 \%$ of the total length) are equipped with lighting and reflective signs. Despite the dense river network of the Cherkasy region, the density of waterways is only $7 \mathrm{~km} /$ thousand $\mathrm{km}^{2}$. On the territory of the region there is a river port and three ports in the city of Kaniv, the town of Irkliev and the village of Adamivka. It is possible to receive ships of the river-sea type.

Air connections are made from Cherkasy airport, which according to its technical characteristics belongs to the 5th class, dimensions and technical condition of the runway allows aircraft type AN-24, Yak-40, L-410, An-2 and An- 26 to operate. In addition, there are a number of airfields and heliports for local air services in the area that are virtually non-operational due to crisis in the industry (Holovne, 2019).

Of great importance among the objects of recreation of he region are its monuments of history and culture, which include monuments of archeology, architecture, arts, history, monuments, historical and cultural reserves. All of them are represented in large numbers on the territory of Cherkasy region and represent the rather impressive resource and recreational potential of the region (Beidyk, 2001).

A large number of archaeological sites pertaining to different periods (Paleolithic, Copper, Bronze, Scythian, early Slavic) and cultures (Trypillya, Zarubinets, Chernyakhiv) are concentrated in Cherkasy region. This is due to the fact that people have inhabited the territory now occupied by the region since ancient times. They explored these spaces as early as the Stone Age - Paleolithic, as evidenced by the various archeological finds of stone tools made about 40 thousand years ago.According to the concentration of various archeological monuments, we can note the areas that most attracted people in all historical periods.A significant accumulation of archeological sites from the Stone Age to the Late Middle Ages is observed along the Dnipro River (right and left banks), some of which are in the floodplain of the Kremenchuk and Kaniv reservoirs. Areas with a high density of archeological monuments include the following rivers ; Tyasmin, Hirskyy Tikych, Hnylyy 
Tikych, Umanka, Revukha, Sinitsa, Udych and their tributaries, small rivers and streams (Novykova, 2006).

Among the archeological sites of greatest interest is the mammoth bone dwelling found at the site of the late Paleolithic (20-15 thousand $\mathrm{BC})$ site, located in the village of Mezhyrich in the Kaniv area. Trypillian culture includes about 100 settlements in the district of Talne, among which are the world-famous settlement-giants near the villages of Talyanka, Vesely Kut, Maidanetske and others. It is on the basis of these monuments that the State Historical and Cultural Reserve «Trypillya Culture» was created in the Talne district. Arrays of Trypillian cultural monuments have also been found in such areas as Zvenigorod, Monastyrische, Uman, Mankiv, Khrystyniv, Lysyansky, Korsun-Shevchenkivsky, Kaniv. The Trakhtemirs State Historical and Cultural Reserve was organized on the basis of settlements, settlements, burial grounds near Buchak village, villages Grigorivka and Trakhtemirs, former villages of Monastyrok, Zarubentsy on the basis of various epochs (from Trypillian, Bronze Age to Kievan Rus). The reserve contains the chronicle of the Zarubsky Monastery and the sanctuary of the Kozak Trakhtemir Monastery (Novykova, 2007).

Archaeological sites of Cherkasy region are not only of great scientific importance but also of considerable cognitive value, so they are widely used and can be used in spiritual and intellectual recreation, in particular for conducting excursions, organizing cultural, educational, educational and business tourism.

Architectural monuments that have historical, scientific, artistic value due to their particular qualities (characteristic, traditional, typical or exclusive, unique) may be represented by individual objects or architectural ensembles and complexes, all of which exist in Cherkasy region. The most prominent and valuable architectural sites and complexes have already been declared monuments of national and local architecture. According to the state register of such objects and complexes, in Cherkassy region there are 152 and 121 respectively. However, these figures do not accurately represent the true situation, in one case, an architectural complex consisting of several objects is counted as one unit, in another, all components of the architectural ensemble are counted as separate objects (for example, almost 100 elements of the National Dendrological Park «Sofiyivka» are considered as separate architectural monuments).

The architectural monuments of Cherkasy region are represented by all groups of architecture (public, sacral, palace, industrial, military). The most numerous are the public and sacral architecture. The architectural monuments in Cherkasy region are distributed fairly evenly, although there are districts with single objects (Drabiv district) or with none (Chernobaiv district). The region has significant architectural and resource potential of national importance, despite the fact that most sites have only local protection status. This gives reason to hope that not only domestic but also foreign tourists will take an interest in the architectural monuments of the region.

Monuments of art in the Cherkasy region are represented by works of fine and decorative arts. Most of them are concentrated in art galleries, museums, art exhibitions or take the form of monuments, park sculptures, decorations of buildings and more. The State Register of Immovable and Movable Monuments of Ukraine includes about 400 art monuments of Cherkasy region, which are of national and local importance. They are all used and can be used in cognitive spiritual and intellectual recreation.

Among the approximately 1600 historical and local monuments of Cherkasy region that are listed in the State Register are those that relate to a particular historical event and those that relate to a specific famous person.

Event recreational resources ( «the mostsignificant manifestations of social and natural movements, landmark events in the history of a certain territory" (Beidyk, Novykova, 2002), including political, military, cultural, economic, environmental events, are very clearly manifested within the region.

The territory of Cherkasy region was a part of the lands on which the core of the early East Slavic lands formed at the beginning of our era. And during the existence of the Kievan Rus, the territory of Cherkasy region was the southern edge of the Kyiv principality. The population of the region played a special role in the emergence and development of Ukrainian Cossacks, the establishment of its militarypolitical organization the Zaporizka Sich, as well as the register of Cossacks.

The main Cossack regiments were formed in such cities as Cherkasy, Korsun, Chyhyryn, Kaniv, Kropyvna, Uman. This is where the state-building processes that led to the formation of the Ukrainian Cossack state in the middle of the seventeenth century arose. The first capital of this state was the city of Chyhyryn. Cherkasy region was one of the main areas of the formation of the Haidamak detachments in Ukraine and the development of the Haidamak movement, which reached its highest elevation in 1768 under the leadership of Maxim Zaliznyak and 
became known under the name of Koliyivshchyna.

At the beginning of 1944, the KorsunShevchenkivsky battle took place in Cherkasy region, one of the largest battles during the Second World War. Nine infantry divisions, the Viking SS armored division, and other fascist units met their ignominious endless end here (Novykova, 2007).

Cherkasy region has a rich resource and recreational potential for reflecting the lives of famous individuals - significant biosocial resources, because the territory of the modern Cherkasy region is the homeland, place of residence and activity of many famous people. Cherkasy region is called the Shevchenko Territory, because Taras Shevchenko was born in the village of Moryntsi (now Zvenigorod district) and found his eternal rest on Chernechia Mountain in Kaniv. The Shevchenko National Reserve and the National Taras Shevchenko Homeland are actively functioning within the oblast. Cherkasy region is also closely related to the name of Bohdan Khmelnytsky: in the village of Subotiv (Chyhyryn district) he spent his childhood years and at his residence in Chyhyryn he received ambassadors from many European countries. From the village of Subotiv, the hetman led the armed forces in the liberation war of the Ukrainian people from 1648 to 1654, where he signed his own universal declaration of service to the people. The hetman is buried in the Church of Elijah.

There are many monuments within the Cherkasy region that perpetuate the memory of certain events as well as of specific people. Among the monuments, historical events are most devoted to the heroic struggle of the Soviet people during the Great Patriotic War. Monuments are erected in the area mainly to prominent figures that were born, worked or buried on Cherkasy land. Ukraine's first monument to Taras Shevchenko's mother, Kateryna Shevchenko, was erected in the village of Moryntsi, Zvenigorod district (on the occasion of the 192nd anniversary (2006) of the Great Kobzar's birthday). This monument symbolizes the bright image of the Mother of God worshiped and loved by the true knights of freedom, the Ukrainian Cossacks, thus honoring all Ukrainian Mothers, the Protectors of our Motherland (Konovalenko, Karastan, 2006).

Cherkasy region's numerous historical and cultural monuments, their great diversity gives grounds for priority development within the region of cognitive spiritual and intellectual recreation (excursions, cultural and cognitive tourism), for which historical and cultural monuments are the main recreational resource. This sphere of recreational activity can develop locally, nationally, globally, as the region has attractions of local, national and international importance.

We also include all kinds of natural monuments, except complex ones, for recreation. These are «monuments» created not by man but by nature. They can be used as display objects for sightseeing and cultural tourism. The 1000-year-old oak of Maxim Zaliznyak, which grows on the Buda farm of Chyhyryn district, is considered the patriarch of forests not only of Cherkasy region but also of Europe. The height of this oak reaches more than $22 \mathrm{~m}$ and the circumference of the trunk is $8.7 \mathrm{~m}$.

The 800-year-old oak tree from Didova Gora (Korsun-Shevchenkivsky district) is called Haidamatsky due to the liberation movement in Ukraine in the 18th century. Shevchenko's oak is located on Mikhailova Gora near Prokhorovka village (Kaniv district). Until recently, the 300-year-old Gogol pine grew there., It is named after the great writer because he loved to rest here while visiting this village in October 1832.

The Three Wells hydrological site is located near the village of Subotiv (Chyhyryn district). It is connected with the events of the struggle of the Ukrainian people against the oppressors under the leadership of B. Khmelnytsky.Among the geological monuments of Cherkasy region are many of great scientific importance. There are a large number of historically significant natural monuments of orographic origin - the rock of Alexander Pushkin made of pink granite on the River Tasmin on the outskirts of Kamianka, the rocks of Ivan NechuyLevitsky, Adam Mickiewicz and others (Konovalenko, Karastan, Karastan, Karastan, 2006).

We also include attractions and landmarks in the recreation group that are not declared as monuments, but which attract the attention of tourists. These can be any spatially-localized material formations of value for spiritual and intellectual recreation, including excursion activities, cultural and cognitive (including ethnographic), business and ethnic tourism: places related to the life and activities of the famous people of a certain ethnic community, with traditional arts and crafts, significant events, outstanding and interesting natural and social phenomena, nostalgic memories and more. The potential of this group of recreational resources in Cherkasy region is still underused.

The traditional material culture in the Cherkasy region is preserved in the form of Ukrainian national clothes, country houses, furniture and interior decoration, tools, utensils and household items. These objects which have been preserved outside 
museums and are being created today can have aesthetic, historical, scientific value and be used as resources for recreational activities. Therefore, it is important to identify and maintain centers of folk crafts and trades.Some of them have survived to this day and are represented by the following types - pottery (villages Mliiv, Starosillya, Sounki, etc.), woodworking (villages Moshny, Bilozirya, Zhabotin, etc.), sheepskin coats (Smila), weaving, pleating, embroidery (in different areas of the region) crafts. The leaders in these types of crafts are Chyhyryn, Mankiv and Chernobaiv districts. We can say that the region has good prospects for cultural and educational recreation, in particular ethnographic tourism.

Sacred structures are an important component of recreational sites. They serve as the basis for spiritual and religious recreation, which attracts believers, pilgrims, researchers. There are more than 540 religious communities on the territory of Cherkasy region, practically each of which has premises for worship. Christian denominations prevail. In their structure, the most numerous is Orthodoxy: more than 270 religious communities belong to the Ukrainian Orthodox Church, about 40 to the Ukrainian Orthodox Church of the Kiev Patriarchate and 14 to the Ukrainian Autocephalous Orthodox Church.

There are 5 monasteries in Cherkasy region, 3 of which are female: Matroninsky Trinity in Chyhyryn district, Trakhtemyrivsky Uspensky in Kaniv district, Krasnogorsk Svyatopokrovsky in Zolotoniski district, and 2 - male monasteries: Lebedinsky Georgievsky in Shpolyan district, Chubovsky Onufrievsky in Cherkasy district. The Onufrievsky Monastery in Cherkasy is restored around the Church of the Nativity of the Blessed Virgin (Konovalenko, Karastan, 2006).

Cherkasy region is rich in water resources. Waterways are used for fishing, shipping and water tourism. In the region there is the southern part of the Kaniv and most of the Kremenchug reservoir, 1037 rivers with a total length of more than 7.5 thousand $\mathrm{km}$, the banks of which are almost universally used for recreation. A large number of reservoirs and ponds (over 2,000) are not only of economic importance but also of recreational importance (Konovalenko and Karastan, 2006).

Lakes and ponds are important recreational areas. All these types of water recreational resources are represented in the studied region, and their surface is $4 \%$ of the area of the region. Waterways are used for bathing, fishing, shipping and more. The largest among them are the Dnipro, the Ros with its tributary the Rosava, the Tyasmin with its tributary the Hnyliy Tashlyk, Supiy, Zolotonoshka, HirskyyTikych with its tributary the Hnylyy Tikych with the Shpolka, Bolshaya Vis, the Yatran with its tributary the Umanka, the Sinitsa. Water sports on inflatable and paddle boats and canoes can be organized on separate sections of the Dnipro and Ros rivers.

Dnipro River cruises along the route «From Varangians to the Greeks» are known not only to Ukrainian but also to foreign tourists. There are more than 2 thousand reservoirs, ponds and lakes in the region. The wide expanses of the Kremenchug and Kaniv reservoirs are chudoviymy places for sailing and windsurfing enthusiasts. More than 30 species of freshwater fish are widespread in the waters of Cherkasy region, among which the most valuable are bream, carp, zander, pike, crucian carp, ziege, tench, catfish, silver carp, white carp (Novykova, 2007).

Conservation areas, which are part of the recreation grounds, are a major recreational resource of the region. Particularly important are those in which the recreational function is leading: national nature parks, regional landscapes, parks, gardens, botanical gardens, arboretums, zoos. There are no botanical gardens and national nature parks in Cherkasy region. However, the Kaniv Nature Reserve with an area of 2,027 hectares now actually performs the functions of a national nature park in the absence of such nature reserve sites in central Ukraine.

Trakhtemyriv Regional Landscape Park (terminologically consistent with the notion of a national nature park of local importance) established in 2000 in Cherkasy (5,562.5 ha) and Kyiv (5,148.7 ha) regions in order to preserve relatively unchanged natural landscapes and natural ecosystems, historical, cultural and archeological heritage.

The world-renowned Sofiyivka National Dendrological Park is called the Pearl of Ukraine. It is one of the unique parks in Europe with magnificent landscapes, numerous water reservoirs, man-made grottoes, exquisite antique sculpture. The collections of plants in the dendropark are listed in the National Heritage Register.

Cherkasy operates one of Ukraine's 7 zoological parks of national importance. More than 120 species of animals are kept here, 13 of which are listed in the Red Data Book of Ukraine. It is also a significant recreational resource of the region (Konovalenko and Karastan, 2006).

The Cherkasy Region Conservation Fund has more than 550 objects covering an area of about 50,000 hectares, which is $1.9 \%$ of the area.However, not all of them can be used for recreational activities, since some objects and territories of the nature reserve fund are declared as such only because of 
their conservation or scientific value, but they may not be of recreational utility, so they are not attractive to people seeking recreation.

In the territory of Cherkasy region 277 objects of the nature reserve fund were found that could be used in recreational activities, with a total area of 25.2 thousand hectares or $1.2 \%$ of the area of the region.

The healing properties of the natural space in Cherkasy region are represented by mineral waters and a healing forest climate. Prophylactic and health recreation and health tourism are developing on their basis.

Mineral waters in areas such as Zvenigorod, Kamyansky and Lysyansky contain significant amounts of radon, iron and bromine and are not inferior to the glorious waters of Tschaltubo, Zheleznovodsk, Yessentuki, and other major resorts in the world. Radon water springs are also found in such areas as Zhashkiv and Uman. Hydrocarbonate sodium-magnesium-calcium waters, located in the town of Talne, are close in composition to oxygenated narzan. Due to the flatness of the Cherkasy region, natural sources of mineral waters (self-leaching) are rare. Wells are often drilled within the region to detect waters with high levels of mineralization with therapeutic effect (Novykova, 2008).

According to the method of Beidyk O.O. (Beidyk, 2010) a point score was used to compare the level of tourism infrastructure development and recreational potential. On this basis, by adding all points and the method of arithmetic, you can reduce all points to a single score, getting a certain number of points for each district of Cherkasy region. This number of points will determine the level of potential of different components of the tourist infrastructure for each of the administrative units of Cherkasy region (Table 1).

The state of provision of tourism potential by administrative districts of Cherkasy region was distributed according to the following levels:

1) Low level from 1.0 to 2.0 points;

2) Average level from 2.1 to 3.0 points;

3) High level from 3.1 to 5.0 points (Fig. 1).

We have made a point assessment of the tourism potential of Cherkasy region by such indicators as hotel infrastructure, restaurant infrastructure, health -improvement establishments, archeology monuments, architectural monuments and historical monuments.Based on the indicators of this scoring, we can distinguish five districts with high levels of tourism potential (Zolotonisky, Kaniv, Uman, Cherkasy, Chigirin), ten districts with average level (Horodyshche, Zvenigorod, Kamyansky, KorsunShevchenkivsky, Mankiv, Smilyansky, Talne,
Khristinoiv, Chernobaiv, Shpolyan), five areasoutsiders with low level of tourism potential (Drabiv, Zhashkiv, Katerynopil, Lysyansky, Monastyrische).

Conclusions. Among the objects of recreation in Cherkasy region is a large number of monuments of archeology, architecture, history, nature, developed centers of traditional crafts and trades, a fairly dense network of sacral structures. Forests and reservoirs play an important role in the recreational area. Conservation-protected areas occupy $1.2 \%$ of the region's area. Mineral waters and healing properties of the forest climate are the main manifestations of the recreational properties of space in Cherkasy region. A significant contribution to the resource component of the recreational potential of Cherkasy region was made by a large number of historical and cultural reserves - of which there are eight at regional level, and two of national status .

The sanatorium-resort and preventive-health establishments of the region are considered. It is established that they are represented by sanatoriums (including children's ones), tourist bases and other recreation establishments, whose number is decreasing every year. It is established that according to the capacity index, the sites with the largest capacity for overnight accommodation of tourists are such resorts as «Svitanok» in the village of Svidovok, «Moshnohirya» in the village of Budyshche, «Akvadar» in the town of Mankivka, children's «Ruska Polyana» in the village of Ruska Polyana of Cherkasy district and «Ukraine» and «Sosnoviy bir», which are located in the city of Cherkasy. The most significant recreation facilities are located in the village of Vigraev, Korsun-Shevchenkivskyi district («Ros») VAT «SPK Merydian», «Dubky», «Ros» (Relay and Automation Plant, Kazar-Ros), Prokhorovka village, Kaniv district («Sonyachna», «Komsomolska»), in the village of Chapayevka of the Zolotonisky district («Prydniprovska»).

It is established that there is an increase in the number of subjects of tourist activity. More than $80 \%$ of them are travel agencies that are not focused on domestic and inbound tourism. It is found that the transport of Cherkasy region is represented by all major passenger types (rail, road, river and air) and its functioning is provided by appropriate infrastructure.

When analyzing the components of the tourism potential of the Cherkasy region by the method of scoring, it can be concluded that in the region there are five districts with high levels of tourism potential, such as: Zolotonisky, Kaniv, Uman, Cherkasy and Chyhyryn.This is due to the fact that in these areas all components of the tourist potential, such as well- 
Table 1 Overall assessment of the tourism potential of the Cherkasy region

\begin{tabular}{|c|c|c|c|}
\hline Administrative districts & $\begin{array}{c}\text { Overall assessment of tourism } \\
\text { infrastructure availability }\end{array}$ & $\begin{array}{c}\text { Overall assessment of the } \\
\text { availability of natural and } \\
\text { recreational facilities }\end{array}$ & $\begin{array}{c}\text { Overall assessment of tourism } \\
\text { potential }\end{array}$ \\
\hline $\mathbf{1}$ & $\mathbf{2}$ & $\mathbf{3}$ & $\mathbf{4}$ \\
\hline Horodyshche & 1.4 & 1.6 & $\mathbf{3}$ \\
\hline Drabiv & 0.7 & 0.6 & $\mathbf{1 . 9}$ \\
\hline Zhashkiv & 0.9 & 1.8 & $\mathbf{2 . 6}$ \\
\hline Zvenigorod & 0.8 & 1.5 & $\mathbf{3 . 4}$ \\
\hline Zolotonisky & 1.9 & 1.3 & $\mathbf{2 . 2}$ \\
\hline Kamyansky & 0.9 & 2.1 & $\mathbf{3 . 5}$ \\
\hline Kaniv & 1.4 & 1 & $\mathbf{1 . 6}$ \\
\hline Katerynopil & 0.6 & 1.8 & $\mathbf{1 . 8}$ \\
\hline Korsun-Shevchenkivsky & 0.9 & 1.1 & $\mathbf{2 . 7}$ \\
\hline Lysyansky & 0.7 & 1.8 & $\mathbf{1 . 6}$ \\
\hline Mankiv & 0.9 & 1 & $\mathbf{2 . 6}$ \\
\hline Monastyrische & 0.6 & 2 & $\mathbf{2 . 4}$ \\
\hline Smilyansky & 0.9 & 1.5 & $\mathbf{3 . 8}$ \\
\hline Talne & 0.9 & 2 & $\mathbf{2 . 2}$ \\
\hline Uman & 1.8 & 1.3 & $\mathbf{4 . 6}$ \\
\hline Khrystyniv & 0.9 & 2.1 & $\mathbf{3 . 9}$ \\
\hline Cherkasy & 2.5 & 2.1 & $\mathbf{2 . 7}$ \\
\hline Chyhyryn & 0.8 & 1.3 & $\mathbf{2 . 9}$ \\
\hline Chernobaiv & 1.4 & 1.8 & \\
\hline Shpolyan & 1.1 & & \\
\hline
\end{tabular}

developed tourist infrastructure and recreational tourist potential: Horodyshche, Zvenihorod, Kamyanresources are strongly represented.

sky, Korsun-Shevchenkivsky, Mankiv, Smilyansky,

Ten districts in the region have average levels of Talne, Khrystyniv, Chornobaiv and Shpolyan. They

\section{State of development of tourist potential}

High (from 3.1 to 5.0 points)

Average (from 2.1 to 3.0 points)

Low (from 1.0 to 2.0 points)

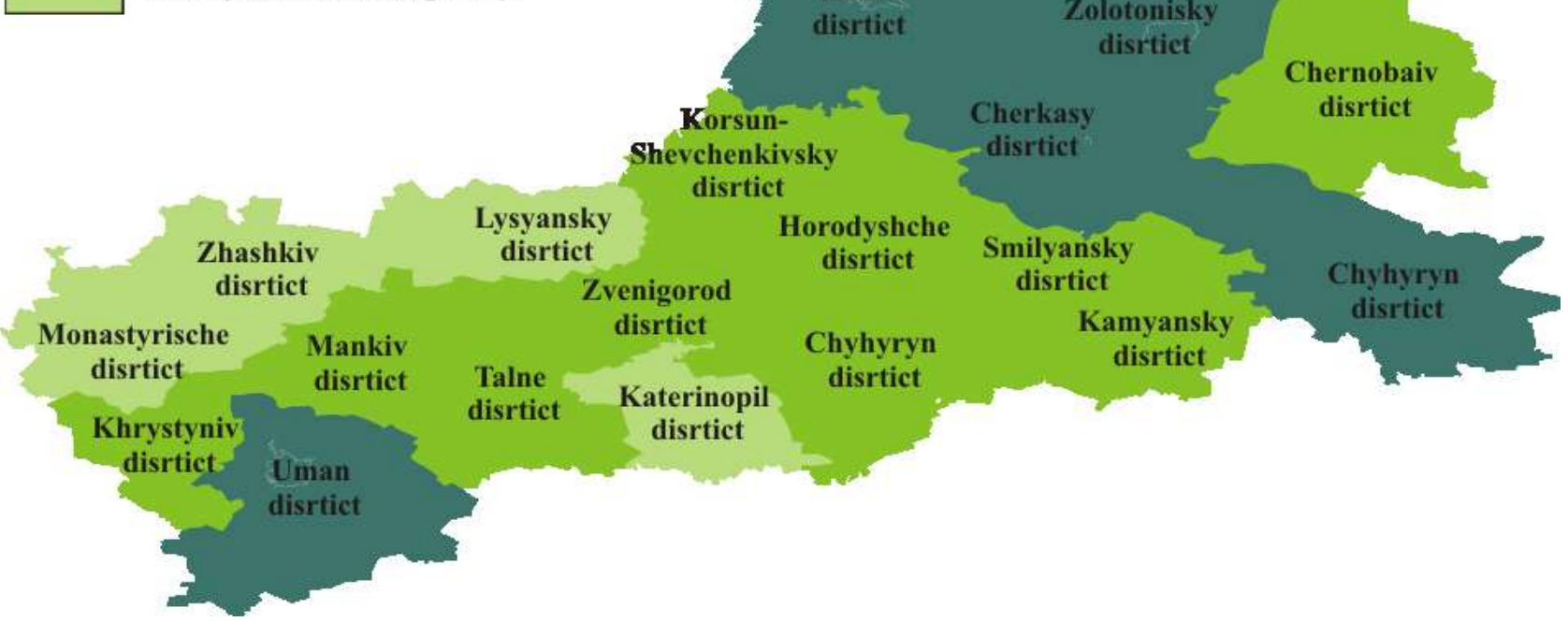

Fig. 1 State provision of tourist potential by administrative districts of Cherkasy region 
are represented by a balanced level of tourism potential.

According to the results of the study, the outsider areas were identified by the low level of tourism potential supply (5 districts): Drabiv, Zhashkiv, Katerynopil, Lysyanskyand Monastyrische. These areas have very weak development in the tourism potential, namely recreational resources and tourist infrastructure.

\section{References}

Beidyk, O.O., 2001. Rekreatsiino-turystski resursy Ukrainy: Metodolohiia i metodyka analizu, terminolohiia, raionuvannia: Monohrafiia [Recreational and tourism resources of Ukraine: Methodology and methods of analysis, terminology, zoning: Monograph]. Kyiv: Publishing and Printing Center «Kyiv University», 395 (in Ukrainian).

Beidyk, O.O., 2010. Rekreatsiini resursy Ukrainy: Navchalnyi posibnyk [Recreational Resources of Ukraine: Textbook]. Kyiv: Alterpress, 404 (in Ukrainian).

Beidyk, O.O., Novykova, V.I., 2002. Rekreatsiino-turystski resursy Serednoho Podniprovia (na prykladi Cherkaskoi oblasti) [Recreational and tourism resources of the Middle Dnieper region (on the example of Cherkasy region)]. Tourism in the $21 \mathrm{st}$ Century: Global Trends and Regional Features: Proceedings of the Second International Scientific and Practical Conference. Kyiv: Znannya Ukrayiny, 485-498 (in Ukrainian).

Cherkaska oblasna rada: ofitsiinyi sait, 2019 [Cherkasy Regional Council: official site]. RetrievedfromURL: https://www.oblradack.gov.ua/ istorychni-ta-kulturni-obekty (in Ukrainian).

Derzhavna sluzhba statystyky Ukrainy: ofitsiinyi sait. Turystychna diialnist Cherkaskoi oblasti, 2019 [State Statistics Service of Ukraine: official site.
Tourist Activity of Cherkasy region] RetrievedfromURL: http://www.ukrstat.gov.ua

Holovne upravlinnia statystyky u Cherkaskii oblasti, 2019

[Main Department of Statistics in Cherkasy Region]. RetrievedfromURL: http://www.ck.ukrstat. gov.ua/ (in Ukrainian).

Konovalenko, O. S., Karastan I. M., 2006.Pryrodno-zapovidnyi fond Cherkaskoi oblasti [Nature Reserve Fund of Cherkasy region]. Cherkasy: Vertical, 196 (in Ukrainian).

Leonenko, V. B., Stetsenko, M. P., Vodnyi, Yu.M., 2003. Atlas obiektiv pryrodno-zapovidnoho fondu Ukrainy [Atlas of Objects of the Nature Reserve Fund of Ukraine]. Kyiv: Kyiv University, 72 (in Ukrainian).

Novykova, V.I., 2006. Rozvytok pryrodno-zapovidnoho fondu Ukrainy: dynamika, perspektyvy, pidsylennia rekreatsiinoi tsinnosti obiektiv [Development of the Nature Reserve Fund of Ukraine: dynamics, prospects, enhancement of the recreational value of objects]. Chernivtsi University Scientific Bulletin: Collection of Scientific Papers. Geography. Chernivtsi: Ruta, Issue 304, 124-133 (in Ukrainian).

Novykova, V.I., 2007. Resursno-rekreatsiinyi potentsial Cherkaskoi oblasti: suspilno-heohrafichna otsinka dlia rekreatsiinoi diialnosti [Resource and recreational potential of Cherkasy region: socio-geographical assessment for recreational activity]. Scientific Notes of Vinnytsia State Pedagogical University named after Mikhail Kotsyubynsky. Geography Series. Vinnitsa: Thesis, Issue 13, 220228 (in Ukrainian).

Novykova, V.I., 2008. Vyiavlennia elementiv terytorialnoi struktury rekreatsiinoi diialnosti $\mathrm{v}$ rehionakh Ukrainy ta Cherkaskii oblasti iz zastosuvanniam metodu kontent-analizu [Identification of elements of the territorial structure of recreational activity in the regions of Ukraine and Cherkasy region using the content analysis method]. Geography and Modernity: Collection of scientific works. Kyiv: Publishing House of M.P. Dragomanov National Pedagogical University, Issue 18, 159-172 (in Ukrainian). 